\title{
The development of working capital management and its impact on profitability and shareholder value: evidence from Germany
}

\author{
Bernadette Högerle \\ Nova School of Business and Economics, Lisbon, Portugal \\ Michel Charifzadeh \\ ESB Business School, Reutlingen University, Reutlingen, Germany \\ Marlene Ferencz \\ ESB Business School, Reutlingen University, Reutlingen, Germany
}

Konstantin B. Kostin

Saint-Petersburg State University of Economics, St. Petersburg, Russia

\begin{abstract}
This study investigates empirically the development of working capital management and its impact on profitability and shareholder value in Germany. We analyse panel data of 115 firms listed on the German Prime Standard, covering the period from 2011 to 2017. The results provide evidence that efficient working capital management, indicated by a shorter cash conversion cycle, deteriorated over time, but that a shorter cash conversion has a positive impact on profitability and shareholder value. The findings highlight the need that managers should give greater priority to working capital optimization, even in a low-interest environment. The paper contributes to the literature by advancing this research area in Germany, and it is the first study investigating shareholder relationship with working capital management and all its determinants.
\end{abstract}

\section{Keywords}

Working capital; working capital management; cash conversion cycle; profitability; return on capital employed; shareholder value; market value added; Germany; panel data.

\section{Introduction}

Working capital management, i.e. the management of current assets and current liabilities, is an aspect of managerial accounting and an important component in a firm's financial success. It can be considered a holistic approach to improving a company's liquidity, profitability, and value (Gitman \& Zutter, 2015). Working capital management had regained in importance during the financial crisis as a source of internal financing when there was limited or no access to external capital (Gleich, Horváth \& Michel, 2011). Consulting firms offer their services in the improvement and optimization of working capital management and regularly publish working capital studies on the current trends in specific regions. Despite the relevance of working capital management, some studies conclude that it has recently been of minor importance due to the lowinterest environment, which provides cheaper financing for companies (Deloitte, 2017; REL Consultancy, 2017). However, also in times of cheap money, working capital management provides enormous cash potentials (Deloitte, 2017) as the working capital components accounts receivable and inventory account for a substantial portion of a company's assets. In the case of the 
firms considered in this paper, the components constitute approximately $23 \%$ of their total assets; further, the calculation of a cash potential revealed that roughly $€ 326$ billion could be released from their balance sheets in 2017 (for the calculation of a cash potential see Seeger et al., 2011). These calculations underline the importance of prioritizing working capital management.

In addition to the regularly published industry studies of consulting firms, numerous scientific studies statistically analyse the positive influence of working capital management on profitability in various countries and contexts (Singh, Kumar \& Colombage, 2017). This study intends to unite the two types of investigation, working capital studies, and statistical research on working capital management and brings them up to date in the context of Germany. The purpose of this research is twofold. First, we empirically examine the development of working capital management, and second, we investigate the impact of working capital management on profitability and shareholder value. Both analyses are based on 115 firms listed on the German Prime Standard for the period from 2011 to 2017 (you can also see an example of analysing an array of data in the source: Westbrook, Pera, Neguriță, Grecu \& Grecu, 2019). The first research question is answered by analysing the variable cash conversion cycle (CCC), a measure for working capital management efficiency, over time (Van der Wielen, Van Alphen, Bergen \& Lindow, 2006). We invest the impact of working capital management with panel data models, in specific with fixed effects (FE) and random effects (RE). The associated dependent variables profitability and shareholder value are estimated with return on capital employed (ROCE) and market value added (MVA), respectively.

This study contributes to research threefold. First, it provides recent evidence on the development of working capital in business firms in Germany. Second, there exist only a few studies investigating the impact of working capital management on profitability in Germany, which are out of date and published in German language only (Meyer \& Lüdtke, 2006; Wöhrmann, Knauer $\&$ Gefken, 2012). Third, this paper contributes to the literature by assessing the relationship of shareholder value with working capital management and all its determinants. So far, the effect of overall working capital management on shareholder value has been confirmed by only few authors, but not for Germany (Kieschnick, Laplante \& Moussawi, 2013; Wang, 2002).

The remainder of this paper is outlined as follows: Section 2 provides a brief theoretical background on working capital and its components. Section 3 presents a literature review and derives the respective hypotheses. Section 4 discusses the research design, which is subdivided in the description of data, the definition of variables and the explanation of the research methods. The empirical results are outlined and discussed in Section 5. The study concludes with a summary of the findings and the resulting implications.

\section{Theoretical background on working capital}

In addition to the investment (see for examples: Subic, Vasiljevic, Andrei, 2010), working capital management is an important area in financial management and relates to the overall management of current assets and current liabilities. Although traditionally working capital refers solely to current assets, this study relates to the more common definition of (net) working capital as the difference between current assets and current liabilities. Hence, it reflects the portion of current assets financed by long-term debt and equity (Schall \& Haley, 1986).

The primary goal of working capital management is to release capital tied up in daily operations to increase liquidity. The released cash can be utilized for internal financing, and the avoided external funding reduces the capital cost (Gleich et al., 2011). Moreover, improvements in working capital do not only increase liquidity but, above all, efficiency in operational processes. The resulting lower costs tend to increase financial profits (Van der Wielen et al., 2006).

In contrast to the main and intellectual capital (see for example Bratianu, 2018), the drivers of working capital management are accounts receivable management, inventory management, and accounts payable management. The underlying idea is to reduce accounts receivable by collecting cash more quickly (e.g. through renegotiating payment terms and granting discounts for early payment, implementation of the principles of sharing economy (see for example Popescu, 2018). Further, accelerating the turnover of inventory, for example by ordering stocks just-in-time through lean manufacturing, lowers stocks. Lastly, firms should maintain higher values of accounts payable as a result of 
delaying payments to suppliers, thus making use of supplier credit (Van der Wielen et al., 2006).

A popular and comprehensive measure of working capital management efficiency used in practice, combining the drivers of working capital, is the cash conversion cycle (CCC) (aspects of cycle theory see for example Isaic, Smirna \& Paun, 2019; Gitman, 1974; Deloof, 2003). The CCC focuses, with its three components days sales outstanding (DSO), days inventory outstanding (DIO) and days payables outstanding (DPO), on the length of time in days it takes a firm to convert the cash invested in its operations into cash flows through purchasing, production, and sales. As shown in figure 1, the CCC is calculated by deducting the payment period (DPO) from the operating cycle (the sum of DSO and DIO), which is the period from the beginning of the production process to the collection of cash and the sale of the finished product. The aim is to reduce the length of the $\mathrm{CCC}$ to a reasonable minimum. The shorter the $\mathrm{CCC}$, the lower the capital requirements (Gitman $\&$ Zutter, 2015). Nevertheless, a positive gap in the CCC is normal for many industries to ensure the smooth running of their business, for example by pre-financing production (Charifzadeh \& Taschner, 2017).

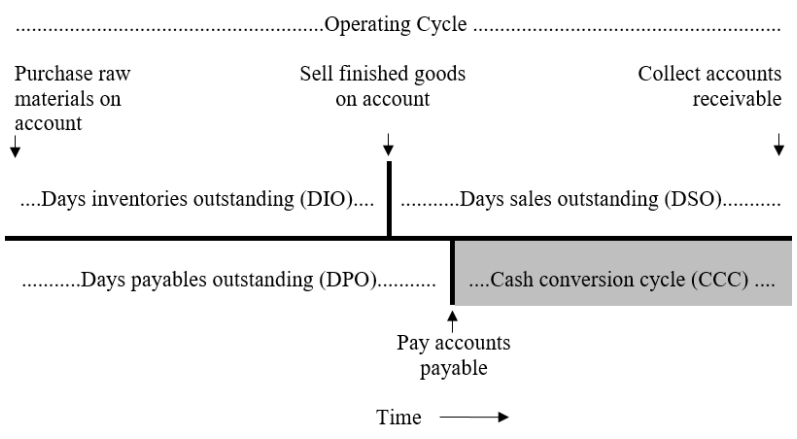

Figure 1 The cash conversion cycle Source: adapted from Gitman \& Zutter, 2015

Practice shows that there exists a trade-off in working capital management between a firm's profitability and risk and hence makes working capital management a task of optimization (Gitman \& Zutter, 2015). For instance, highpressure collection techniques might deter potential customers and lead to lost sales. Keeping inventory too low risks stock-outs, not being able to respond to sales peaks or special customer needs, and a bad reputation among customers (see foe example Pauna, 2019). Further, a firm cannot delay payments indefinitely, because it would risk good relationships with suppliers, creditworthiness (restricted access to bank credits) and legal consequences (Van der Wielen et al., 2006). The critical question is, therefore, how and to what extent companies must manage their working capital in order to keep it as low as possible but as high as necessary (Gleich et al., 2011; Charifzadeh \& Taschner, 2017).

The sufficient level of working capital largely depends on a company's industry and client base (Van der Wielen et al., 2006). Some industries, such as pharmaceuticals and industrial production, have inherently high levels of capital requirements and large cash gaps, whereas other sectors such as the telecommunication industry even achieve to manage a negative CCC (PricewaterhouseCoopers, 2017).

From a broader perspective, working capital management also plays an integral part in the overall corporate strategy to create shareholder value. Rappaport (1986), who initiated the shareholder revolution in the 1990s with the goal to integrate value orientation as a principle of modern governance, emphasizes already in his standard 1986 work the particular role of working capital in determining shareholder value. He incorporates working capital investment as a key value driver into his shareholder value network, which has a direct impact on operating cash flow and thus on value creation (Rappaport, 1998). In particular, changes in working capital are added (increase in working capital) or subtracted (decrease in working capital) from the forecast operating cash flows and discounted to a present value (Rappaport, 1999). The discounted cash flow (DCF) approach recommended by Rappaport has become popular in corporate valuation and is the most common technique alongside other approaches such as the multiples method or market valuation (Brotherson, Eades, Harris \& Higgins, 2014; Koller, Goedhart \& Wessels, 2015). The direct link between working capital and the DCF approach is a core reason why companies put a lot of effort into working capital optimization.

\section{Literature review and hypothesis development}

\subsection{The development of working capital management}

Regarding the levels of working capital in companies over time, there exists a number of non-academic studies by accounting and consulting firms. These companies have 
discovered working capital management as a promising line of business and are offering their working capital reduction services as an opportunity to create shareholder value and liquidity. The following review summarizes the most relevant findings of their recently published studies.

A study by PricewaterhouseCoopers (PwC) showed a slight decrease of CCC in $2017(-0.4$ days), but a deterioration from 2013 to 2017 by 1.3 days (PricewaterhouseCoopers, 2018). They found a worsening of DSO and DIO over this period, which was mostly offset by a vast improvement in DPO, i.e., accounts payable management. They commented on this development as problematic and unsustainable in the long term, since the cash burden is passed down the value chain, which increases the risk (including financial risk (see for example Valaskova, Kliestik \& Kovacova, 2018)) for all parties. The study further states that investment was sacrificed to maintain cash flows, which, in the long run, will pose a threat to their growth. No link is made to profitability or value of a firm.

The "Europe Working Capital Survey 2017" conducted by REL Consultancy (2017) found a similar development in working capital management and its components for the 1,000 largest non-financial companies in Europe from 2008 to 2016 . The study further explained that the increased payment periods are probably a consequence of the recently implemented late payment directive in the European Union in 2017. It defines that suppliers need to be paid within 60 days latest and it intends to prevent late payments, harming particularly small and medium-sized enterprises (SMEs) in countries like Spain and Italy. According to the study, countries with shorter payment terms reacted and started to extend their payments to 60 days, consequently hurting credit periods.

Also, PwC's working capital study on the countries Germany, Austria, and Switzerland from 2007 to 2017 is in line with global and European development (PricewaterhouseCoopers, 2017).

Deloitte's working capital study 2017 on the 213 biggest German non-financial firms from 2010 to 2015 showed opposite results to the previously presented studies, with a slight improvement in the CCC by one day. The firms' DSO and DIO improved, whereas DPO worsened (Deloitte, 2017).

In summary, working capital management performance slightly deteriorated over the last years from an international perspective, whereas studies covering Germany, the country of interest, showed an opposing trend. This research updates the development of working capital in Germany by testing whether the positive development can be confirmed for the underlying data sample:

H1: Working capital management in Germany improved during the period from 2011 to 2017.

\subsection{The impact of working capital management on profits of domestic and international corporations}

A large body of empirical research addresses the impact of working capital management on profitability. Most of these studies focus on specific countries, conduct multi-sector analysis and exclude financial firms in their investigation due to the specific nature of their activities. The research field initially emerged in the United States and became popular in Asia. Also in Europe researchers increasingly assess the topic (Singh \& Kumar, 2014).

The pioneer works of Jose, Lancaster, and Stevens (1996), Shin and Soenen (1998) and Wang (2002) introduced the CCC as a measure for working capital management. Jose et al. (1996) conducted multiple regression analysis for 2,718 U.S. firms from 1974 to 1993 . They found that the independent variable working capital management, defined as a shorter $\mathrm{CCC}$, relates positively with the dependent variable profitability, measured with return on assets (ROA) and return on equity (ROE). The same relationship was found by Wang (2002) for 1,555 Japanese and Taiwan firms between 1985 and 1996. Shin and Soenen (1998) covered a similar sample as Jose et al. (1996) and likewise found a negative association between the length of the $\mathrm{CCC}$ and two operating margin ratios.

Subsequent studies consistently assessed working capital management with the CCC, although with slightly differing definitions. Researchers additionally started to analyse the CCC components DSO, DIO, and DPO individually. The literature shows a consistent approach in the methodology, namely conducting correlation analysis and different types of regressions for panel data. Most frequently pooled ordinary least squares (OLS) or fixed effects (FE) regression is applied (e.g., Deloof, 2003; García-Teruel \& Martínez-Solano, 2007; Pais \& Gama, 2015). FE models reduce the issue of correlated error terms, a violation of the regression assumption, which is often present in 
panel data (Greene, 2003). Additionally, the inclusion of control variables in the regression equation is standard, yet these variables are not of great interest (Deloof, 2003; García-Teruel \& Martínez-Solano, 2007; Lazaridis \& Tryfonidis, 2006).

One of the most influential studies is the work of Deloof (2003). Deloof's motivation to conduct the study was the large amounts of cash firms invested in working capital, whereupon the author concluded that working capital management must have a significant impact on firms' profitability. For a sample of 1,009 firms in Belgium from 1992 to 1996, the study found a negative and significant relationship of the CCC and all its components (DSO, DIO, and DPO) with gross operating income (GOI). Another paper showed identical results by assessing the same relationship with GOI but in the context of the Athen Stock Exchange (Lazaridis \& Tryfonidis, 2006). García-Teruel and Martínez-Solano (2007) introduced the investigation on SMEs with the argument that for them the management of shortterm assets and liabilities is especially relevant. They analysed 8,872 companies in Spain, covering the years 1996 to 2002, and gave evidence for a negative and significant relationship of DSO and DIO with ROA; they also found a negative relationship with DPO, however, the negative impact was not significant. Pais and Gama (2015) and Lyngstadaas and Berg (2016) are one of the authors who likewise focused on SMEs in Portugal and Norway respectively. Other authors, like Eljelly (2004), Taghizadeh, Ghanavati, Akbari and Ebrati (2012), and Singhania and Mehta (2017) focused on emerging markets. Yet another author, namely Enqvist, Graham and Nikkinen (2014) studied the role of business cycles in the link between working capital and corporate performance by implementing recession and boom dummy variables.

Only a few studies found a positive relationship between working capital management and profitability, which object theory. Sharma and Kumar (2011) found a positive correlation for 263 Indian firms listed on the Bombay Stock Exchange, but the authors drew conclusions from statistically insignificant results.

The role of accounts payable in working capital management is controversial and little discussed. In empirical findings, DPO is often negatively correlated (Enqvist et al., 2014; Lazaridis \& Tryfonidis, 2006). This effect is inconsistent with the theoretical view that a shorter CCC, which can be achieved through the extension of payments to suppliers, leads to higher profitability. An often repeated argument by Deloof (2003) is that less profitable firms wait longer to pay their bills, or that companies redeem substantial discounts for early payments. However, no other study tried to give further explanations (e.g. Enqvist et al., 2014; Lazaridis \& Tryfonidis, 2006; Raheman \& Nasr, 2007). Since the negative effect was also sometimes found to be insignificant, this relation remains unclear (García-Teruel \& Martínez-Solano, 2007; Meyer \& Lüdtke, 2006).

In Germany, there are only two studies on the impact of working capital management on profitability published in German language. First, Meyer and Lüdtke (2006) considered the relationship between working capital management and ROCE for 7,420 selected German firms covering the single year 2003. The only significant result was that a higher inventory turnover positively influences a firm's profitability. As the authors were not able to prove the findings of previous research, they suggested extending the work with a longer period. Six years later, Wöhrmann et al. (2012) continued the research and considered working capital management of 4,963 German firms in light of the financial crisis (2007-2009). Their research motivation was the need for internal financing in times of crisis and the question of whether too aggressive working capital management, e.g., too aggressive receivable management, might harm customer relations. The conducted regression analysis, with ROCE as the dependent variable, revealed a positive impact of working capital management on profitability. In specific, they found a negative and statistically significant relationship for the ROCE with DIO, a positive and statistically significant relationship with DPO, and a positive but not statistically significant association with DSO.

Overall, empirical research, nationally as well as internationally, shows fairly consistent results and provides evidence of an inverse relationship between efficient working capital management, measured with the CCC and profitability ratios. This paper intends to add to the research of Wöhrmann et al. (2012) for the subsequent years 2011 to 2017 after the financial crisis. This leads to the following hypothesis: 
H2.1: Efficient working capital management has a positive impact on the profitability of German firms.

\subsection{The impact of working capital management on shareholder value}

In addition to Rappaport's (1999) reasoning that in a discounted cash flow approach changes in working capital reflect on the cash flow calculation, working capital management contributes to shareholder value creation mainly through the capital charge. The capital charge is the product of a firm's capital employed and its cost of capital (Young \& O'Byrne, 2001). Since working capital is part of the capital employed, a firm can operate with a lower capital charge by economizing in working capital. A lower capital charge, in turn, results in an increase in value.

Many of the previously mentioned papers concluded that working capital management also increases shareholder value, even though they only considered traditional profitability measures (e.g., Deloof, 2003; Meyer \& Lüdtke, 2006; Shin \& Soenen, 1998) and do not test the relationship to value. Profitability measures are inappropriate to determine the creation of shareholder value as accounting profit terms do not account for the entire cost of capital and are subject to accounting principles (Rappaport, 1999; Charifzadeh \& Taschner, 2017).

There exist only a few published papers that handle the shareholder value relationship using a different measurement approach. Kieschnick et al. (2013) adopted an integrated cash flow approach to working capital management by following the base-line valuation model of Faulkender and Wang (2006). Their results show that, on average, U.S. corporations value an additional dollar invested in net operating working capital less than a dollar held in cash.

Wang (2002) takes a simpler approach by assessing the impact of working capital management on corporate value with the metric Tobin's Q, the market value of equity and book value of debt over the book value of total assets. No such study exists for the German market. The following hypothesis generalizes the positive relationship between shareholder wealth and working capital management found by Kieschnick et al. (2013):

H2.2: Efficient working capital management has a positive impact on shareholder value.

\section{Research design}

\subsection{Data}

The data sample for testing the hypothesis consists of all listed firms on the Prime Standard, a segment of the Frankfurt Stock Exchange, at the end of the year 2017. Its composition was retrieved from the German newspaper "BörsenZeitung". Due to its high transparency, its great influence on the German economy, and its diversity (mix of classic, technological and topselling companies from various industries), the Prime Standard can be regarded as a representative sample for the German economy.

All calendar year data from 2011 to 2017 were retrieved from the FactSet Research System. For the conducted analysis, the firms were classified according to the nine supersectors in the German stock index (DAX): Consumer Goods, FIRE (Finance, Insurance, and Real estate), Basic Materials, Industrials, Consumer Services, Pharma \& Healthcare, Information Technology, Tele-Communication, and Utilities (Deutsche Börse AG, 2017). Consistent with previous research, the FIRE sector was excluded from the data sample as well as firms with incomplete data. The sample consists of 116 firms or 812 firm-year observations for the analysis with ROCE and 784 firm-year observations for MVA. To prevent biased results in the analysis, one outlier firm was eliminated from the data. Hence, the final sample represents a balanced panel with $\mathrm{n}=115$ firms, $\mathrm{T}=7$ years, and $\mathrm{N}=805$ observations for the analysis with ROCE, and an unbalanced panel with $\mathrm{n}=115$ firms, $\mathrm{T}=3-7$ years, and $\mathrm{N}=777$ observations for the analysis with MVA.

\subsection{Variables}

When analysing the relationship between working capital management and profitability, most studies assessed profitability with GOI or ROA (Knauer \& Wöhrmann, 2013). An alternative return ratio, which is quite popular in practice, is the return on capital employed (ROCE). ROCE considers only capital, equity, and debt, for which their providers, shareholders, and creditors, require a return. We, therefore, consider ROCE as more appropriate for measuring profitability in our study, because it assesses financing and operating performance showing how efficiently a company is utilizing its capital to generate profits to shareholders and creditors (Whiting, 1986). ROCE is calculated as earnings before interest and taxes (EBIT) over capital employed (CE). 
The latter figure is calculated as the average of the current and the last period, to overcome the different time dimensions of the income statement and balance sheet figures.

Figure 2 depicts that working capital has both a direct and indirect effect on ROCE. Efficient working capital management directly reduces the CE of a company by reducing the capital tied up in operations. The indirect effect is that efficient working capital management improves operational processes and consequently reduces operating costs, which should have a positive effect on EBIT. Conceptually, both effects should lead to an increase in ROCE (Simons, 2000).

\begin{tabular}{|l|l|l|l|}
\hline \multicolumn{3}{|c|}{ ROCE \% $\uparrow$} \\
\hline \multirow{2}{*}{ EBIT $\uparrow$} & \multicolumn{2}{c|}{ Capital employed $\downarrow$} \\
\hline \multirow{2}{*}{ Sales } & Operating costs $\downarrow$ & Working capital $\downarrow$ & Fixed assets \\
\hline
\end{tabular}

Figure 2 The effect of working capital on return on capital employed

Source: adapted from Gleich et al., 2011

ROCE is not a measure of shareholder value creation, though. We operationalize shareholder value creation by using the metric market value added (MVA). MVA represents the additional value that management creates beyond the capital employed (CE), provided by both shareholders and bondholders (Stern \& Shiely, 2001). Consequently, it is a suitable extension to the profitability ratio ROCE. If a company's market value exceeds $\mathrm{CE}$, reflected by a positive MVA, this indicates value creation. The firm's management aim should be to create as much MVA as possible. The metric MVA is conceptually linked to the free cash flow model of valuation and can be calculated as the sum of all future economic value added (EVA) discounted at the cost of capital (MVA ex-ante) (Hoke, 2002). Yet, as this study solely relies on data available to external analysts, MVA is calculated according to another common approach, which is the difference between the market value and $\mathrm{CE}$ (MVA ex-post) (Young \& O'Byrne, 2001). Theoretically, efficient working capital management increases MVA by reducing $\mathrm{CE}$ and accordingly the deduction base from the market value.

The explanatory variables for ROCE and MVA are the working capital measures DSO, DIO, DPO, and CCC. The variables' advantage is that they provide relative, not absolute, information, thereby making cross-company comparison possible (Knauer \& Wöhrmann,
2013). The ratios' computation follows previous studies in this field (Jose et al. 1996; Shin \& Soenen, 1998; Deloof, 2003) but requires averages for the balance sheet figures to account for volatile balance sheet positions (Charifzadeh \& Taschner, 2017).

Several control variables were considered in the regression, to test the relative and causal relationship between working capital management and the dependent variables ROCE and MVA (Mooi \& Sarstedt, 2011). The choice of the control variables was inspired by previous studies (e.g., Deloof, 2003; Sharma \& Kumar, 2011). The size of the firm (SIZE) is calculated as the natural logarithm of sales because the log transformation minimizes both heteroscedasticity and the influence of outliers in the regression model (Jose et al., 1996). Growth in sales (SGROWTH) is measured as (Salest - Salest-1 / Salest-1); firm leverage (LEV) is obtained by taking total debt over total assets; industry differences are controlled through dummy variables (IND) ranking the nine DAXsupersectors from 9= highest capital intensity to $1=$ lowest capital intensity to be able to draw useful conclusions in the analysis (ranking based on PricewaterhouseCoopers, 2017).

\subsection{Methodology}

\subsubsection{The development of working capital management}

The hypothesis that working capital management in Germany improved over the period from 2011 to 2017 was tested by calculating the averages of the CCC for each year. Efficient working capital management improved if the CCC declined in the investigated period, comparing the years 2011 and 2017. Additionally, the percentage change of the CCC for all seven years was calculated and averaged to see whether the overall change was negative, giving evidence for an improvement in working capital management. This two-step approach ensures the exclusion of possible onetime effects in 2011 or 2017.

To gain further insights, the development was broken down into the CCC's components and the individual industries.

\subsubsection{The impact of working capital management}

The second hypothesis, which considers the impact of working capital management on profitability and shareholder value, was tested by 
conducting panel data regression following Deloof (2003). For the regressions with ROCE, the Hausman test indicates the fixed effects model (FE) while for the regressions with MVA, random effects (RE) is preferred (Hausman, 1978).

It is important to measure each working capital component separately with the control variables to determine their individual effects (Knauer and Wöhrmann, 2013). Hence, to investigate the relationship with ROCE we consider four regressions with fixed effect estimates and for MVA four regressions with random effect estimates. We investigate in series the effect of the independent variables CCC, DSO, DIO, and DPO on ROCE and MVA respectively, always with the same control variables: size, growth, leverage, and industry. To account for possible heteroscedasticity and autocorrelation, we apply Newey-West (NW) robust standard errors (Newey and West, 1987).

To account for possible heteroscedasticity and autocorrelation, we apply Newey-West (NW) robust standard errors (Newey \& West, 1987).

\section{Empirical analysis and discussion}

Table 1 shows the descriptive statistics for the adjusted data sample, containing 115 German firms over the period from 2011 to 2017.

Table 1 Descriptive statistics

\begin{tabular}{l|l|l|l|l}
\hline & Mean & Minimum & Maximum & $\begin{array}{l}\text { Standard } \\
\text { deviation }\end{array}$ \\
\hline ROCE (in \%) & 9.69 & -41.33 & 50.00 & 9.21 \\
\hline $\begin{array}{l}\text { MVA } \\
\text { (in million } € \text { ) }\end{array}$ & 416 & $-161,661$ & 195,032 & 16,192 \\
\hline CCC (in days) & 68 & -79 & 320 & 63 \\
\hline DSO (in days) & 57 & 1 & 192 & 26 \\
\hline DIO (in days) & 67 & 0 & 269 & 53 \\
\hline DPO (in days) & 56 & 5 & 257 & 33 \\
\hline SIZE & 8 & 2 & 12 & 1.80 \\
\hline $\begin{array}{l}\text { SGROWTH (in } \\
\%)\end{array}$ & 7.99 & -67.15 & 260.76 & 20.75 \\
\hline LEV (in \%) & 20.91 & 0.00 & 99.96 & 15.15 \\
\hline IND & 7 & 1 & 9 & 2.19 \\
\hline & & & \multicolumn{2}{|c}{ Source: The Authors }
\end{tabular}

ROCE for the sample is on average $9.69 \%$. The mean for MVA is $€ 416$ million, and the variable has a high standard deviation because it is an absolute measure, therefore showing higher variation than ratios. The average CCC is 68 days. Firms collect their sales from costumers after an average of 57 days, it takes them on average 67 days to sell their inventory, and they wait on average 56 days to pay their bills. The mean value for the variable SIZE indicates that most of the investigated firms generate high turnovers, which reflects the composition of the Prime Standard. The firms' mean sales growth is $7.99 \%$, and on average $20.91 \%$ of all assets are financed with financial debt. The values for IND indicate the dummy variable's range.

\subsection{The development of working capital management}

Figure 3 shows the line graphs for the CCC and its components and reveals a relatively flat line for the CCC from 2011 to 2017. The length of the CCC changed only slightly with an increase by one day from 67 to 68 days. Averaging the yearly changes in the $\mathrm{CCC}$ results in an average increase of $0.28 \%$. The results give evidence to reject hypothesis 1 , with the conclusion that working capital management deteriorated from 2011 to 2017. Considering the CCC components individually, inventory constitutes the largest proportion of the CCC followed by accounts receivable and accounts payable. Over the time period, DSO and DIO increased by three days and one day, respectively. DPO lengthened by five days.

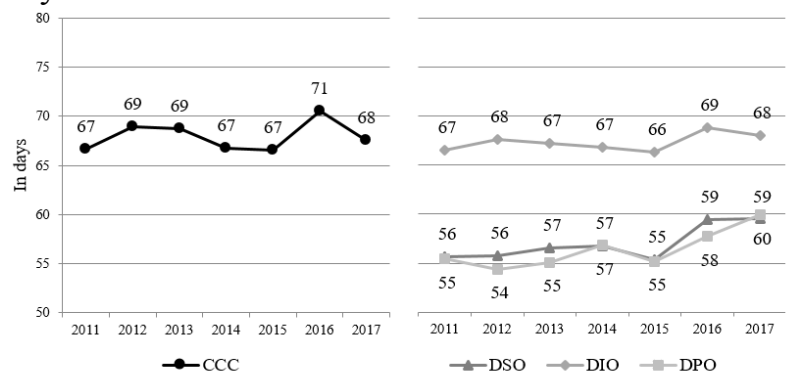

Figure 3 The cash conversion cycle and its components; development $2011-2017$

Source: The Authors

These findings are not in line with Deloitte's working capital study on Germany, which found a decrease in the CCC by one day from 2010 to 2015 (Deloitte, 2017). Our findings confirm the results of the more international studies, which revealed a small deterioration in working capital management. We also see an unsustainable development of a substantial increase in DPO that partially offsets the increase in DSO and DIO.

Further analysis of the individual industries included in the sample reveals that all industries, except telecommunication, consumer services, 
and utilities, show an increase in the CCC. Telecommunication and consumer services outperform the others, with an average CCC of minus five days and ten days, respectively (figure 4). The reason for this achievement is that being service industries, both exhibit rather low inventory levels, with telecommunications showing very low figures for DIO. Additionally, telecommunications achieved a considerable increase in the length of DPO compared to other industries. The sector consumer services performs well because it manages the most extended payment periods, and it is the second-best performer in receivable and inventory management.

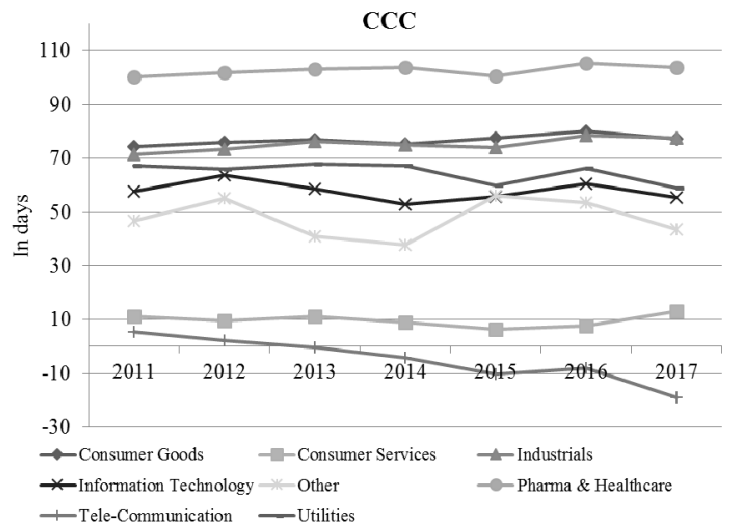

Figure 4 The cash conversion cycle across industries $2011-2017$

Source: The Authors

When comparing the best performers of the $\mathrm{CCC}$ with the best performing industries in DSO, $\mathrm{DIO}$, and DPO, it becomes clear that inventory management determines whether a company achieves to manage a short $\mathrm{CCC}$, which is consistent with the findings of Lind, Pirttilä, Viskari, Schupp \& Kärri (2012) who showed this for the automotive industry. The dominant role of DIO makes sense, as inventory constitutes the largest proportion of the CCC (figure 4). Especially poorly, caused by slow inventory turnover, performs the pharma \& healthcare and the consumer goods industry.

\subsection{The impact of working capital management}

Table 2 shows the results for the FE estimation of ROCE using Newey-West (NW) robust standard errors. As the FE model eliminates anything that is time-invariant, the dummy variable IND drops in the ROCE regression models (Wooldridge, 2016).
Table 2 Regression output for ROCE; estimates and NW standard errors

\begin{tabular}{|c|c|c|c|c|}
\hline Model & (1) & (2) & (3) & (4) \\
\hline $\mathrm{CCC}$ & $\begin{array}{c}-0.0708 \\
* * * \\
(0.02)\end{array}$ & & & \\
\hline DSO & & $\begin{array}{c}-0.0758 \\
* * \\
(0.02)\end{array}$ & & \\
\hline $\mathrm{DIO}$ & & & $\begin{array}{c}-0.0735 \\
* * * \\
(0.02)\end{array}$ & \\
\hline DPO & & & & $\begin{array}{c}0.0018 \\
(0.02) \\
\end{array}$ \\
\hline SIZE & $\begin{array}{l}2.27^{* *} \\
(0.83)\end{array}$ & $\begin{array}{l}2.24 \text { ** } \\
(0.84)\end{array}$ & $\begin{array}{l}2.20 \text { * } \\
(0.86)\end{array}$ & $\begin{array}{l}2.40 \text { ** } \\
(0.91)\end{array}$ \\
\hline SGROWTH & $\begin{array}{c}0.0140 \\
(0.01)\end{array}$ & $\begin{array}{c}0.0121 \\
(0.01)\end{array}$ & $\begin{array}{r}0.0189 \\
(0.01) \\
\end{array}$ & $\begin{array}{r}0.0248^{\prime} \\
(0.01) \\
\end{array}$ \\
\hline LEV & $\begin{array}{c}-0.0967 \\
* * * \\
(0.03)\end{array}$ & $\begin{array}{c}-0.1151 \\
* * * \\
(0.03)\end{array}$ & $\begin{array}{c}-0.1124^{* * *} \\
(0.03)\end{array}$ & $\begin{array}{c}-0.1106^{* * *} \\
(0.03)\end{array}$ \\
\hline IND & - & - & - & - \\
\hline R Square & 0.1086 & 0.0829 & 0.0873 & 0.0597 \\
\hline F-statistic & $20.89^{* * *}$ & $\underset{* \star *}{15.51}$ & $16.40^{* * *}$ & $10.89 * * *$ \\
\hline \multicolumn{5}{|c|}{ Note: Significance level at ${ }^{* * *} 0.1 \%,{ }^{* *} 1 \%,{ }^{*} 5 \%,{ }^{1} 10 \%$} \\
\hline
\end{tabular}

All Models (1) through (4) regress ROCE as the dependent variable against $\mathrm{CCC}$ and its components. The estimates for CCC, DSO, and DIO respectively are negative and highly significant. Consistent with Deloof (2003), these results imply that a shorter CCC, achieved with the faster collection of accounts receivable and higher inventory turnover, positively contributes to a firm's profitability. The coefficient for accounts payable management, measured with $\mathrm{DPO}$, is positive but not significant.

Comparing the coefficients of the significant working capital components shows that these key figures have approximately the same impact on profitability. Across firms and over time, an additional day increase in CCC, DSO, or DIO would yield in a reduction of ROCE of roughly 0.07 percentage points.

The control variables indicate that profitability tends to increase with the size and the sales growth of a firm, yet the latter effect is not statistically significant. A firm's leverage is significantly negatively related to ROCE, implying that a higher debt ratio results in lower profitability. To conclude, the results of regression models (1) to (4) offer strong evidence that efficient working capital management, indicated by a shorter $\mathrm{CCC}$, improves 
profitability, which consequently leads to the acceptance of hypothesis 2.1 .

These relationships are consistent with most previous studies (e.g. Deloof, 2003; García-Teruel \& Martínez-Solano, 2007; Lyngstadaas and Berg, 2016), except for the results for DPO. Most studies found a negative relation for DPO, contradicting theory postulating a higher DPO leading to lower working capital requirements, thus to higher profitability.

Table 3 shows the results for the random effect (RE) estimation of MVA using similar to previous estimation, Newey-West (NW) standard errors.

Table 3 Regression output for MVA; estimates and NW standard errors

\begin{tabular}{l|c|c|c|c}
\multicolumn{1}{c|}{ Model } & (I) & (II) & (III) & (IV) \\
\hline CCC & $\begin{array}{c}-26.80^{*} \\
(11)\end{array}$ & & & \\
\hline DSO & & -15.17 & & \\
\hline DIO & & & -5.77 & \\
& & & $(10)$ & \\
\hline DPO & & & & $51.69 * *$ \\
& & & & $(19)$ \\
\hline SIZE & -689.26 & -602.676 & -575.25 & -694.02 \\
& $(970.04)$ & $(-0.61)$ & $(849)$ & $(879)$ \\
\hline SGROWTH & -2.29 & 3.48 & 4.17 & 8.57 \\
& $(28)$ & $(26)$ & $(26)$ & $(26)$ \\
\hline LEV & -181.64 & -177.51 & -179.48 & $-168.69 * * *$ \\
& $(4 * *$ & $(42)$ & $(44)$ & $(41)$ \\
\hline IND & $667^{* *}$ & $436.65^{*}$ & $412.15^{*}$ & $458.52 *$ \\
& $(202)$ & $(205)$ & $(209)$ & $(211)$ \\
\hline Intercept & 6963.71 & 6778.17 & 6292.67 & 3358 \\
\hline R Square & 0.0362 & 0.0239 & 0.023 & 0.0196 \\
\hline Chisq: & $28.83^{* * *}$ & $11.868 * *$ & $17.34 * * *$ & $15.396 * * *$ \\
\hline
\end{tabular}

Note: Significance level at ${ }^{* \star *} 0.1 \%,{ }^{* *} 1 \%,{ }^{*} 5 \%,{ }^{1} 10 \%$

Source: The Authors

Similar to the regression with ROCE, model (I) shows a negative estimate for $\mathrm{CCC}$, meaning that a shorter financing gap has a positive impact on shareholder value, measured by MVA. In contrast to the ROCE model, where the negative relations of accounts receivable and inventory are highly significant and negative, the effects become insignificant in model (II) and model (III). Contrary, the positive impact of DPO in Model (IV) becomes highly significant in the regression with MVA. Thus, we find evidence that making use of trade credit by deferring payments to suppliers increases shareholder value.
Interpreting the regression results with MVA as a whole, DPO has the highest effect on shareholder value, implying that an additional day in DPO would increase MVA on average by $€ 51.69$ million. The interplay of the working capital components, measured by the CCC, has the second largest impact and reduces MVA by $€ 26.80$ million per one additional day in the CCC.

The control variables SIZE and SGROWTH in the light of MVA exhibit very low significance levels. Also, the variable IND is not statistically significant. For the control variable firm leverage (LEV) we find a significant negative relationship in the MVA models, like in the ROCE models.

In conclusion, the results of regression models (I) and (IV) suggest that improved working capital management has a positive impact on shareholder value, hence leading to the acceptance of hypothesis 2.2. This view is in line with Kieschnick et al. (2013) who proved this relationship with an alternative integrated cash flow approach. It is also in line with theory as shareholder value is measured by the difference between the market value and CE (MVA ex-post).

It is worth further discussing the ambiguous role of accounts payable in working capital management because our findings indicate a positive, yet not significant, relationship with profitability in contrast to the majority of papers (e.g. Deloof, 2003; Enqvist et al., 2014; García-Teruel \& Martínez-Solano, 2007; Padachi, 2006; Pais \& Gama, 2015; Raheman \& Nasr, 2007). Moodley Ward \& Muller (2016) dedicated a whole research paper to this topic criticizing the negative relationship of payables found in many studies as a contradiction to theory. They proposed to consider a holistic metric such as long-term return to investors instead of profitability. Applying a portfolio analysis, they found a positive association between payable days and shareholder return for companies in sectors with significant investments in payables (matching the majority of industries included in this research), hence supporting working capital management theory.

Our findings suggest a highly significant positive impact of DPO on the shareholder value measure MVA and thus support the criticism of Moodley et al. (2016). The positive, though not significant, relationship with ROCE might underlie the same explanation, because the ratio is often considered as a value-based metric (Holler, 2009), therefore resembling shareholder value more than traditional return measures. ROCE 
considered in a value-based context would also explain the positive relationship for payables found by Wöhrmann et al. (2012) who likewise calculated with ROCE.

\section{Conclusion}

This study examines the relationship between working capital management and profitability as well as shareholder value. We conducted panel data analysis for a sample of 115 firms and 805 firm-year observations in Germany covering the period from 2011 to 2017 . We find that working capital management slightly deteriorated in Germany in the analysed period. In specific, the CCC increased by one day or an average of $0.28 \%$. This increase is caused by an unsustainable development of a substantial increase in DSO and DIO, which is partially offset by longer payment periods. By analysing the performance of individual industries, we find supporting evidence, that inventory management is the key factor that determines whether companies achieve a short cash conversion.

Our regression analysis reveals that a shorter CCC increases ROCE. These findings are highly significant. Likewise, the analysis of the determinants of CCC shows that a shorter DSO and DIO have a positive and significant impact on profitability. The positive relationship of days payables and ROCE is not significant, though.

Prior empirical studies have focused primarily on the effect of working capital management on firm profitability (e.g., Deloof, 2003; Meyer \& Lüdtke, 2006; Shin \& Soenen, 1998) but failed to investigate the relationship with value. Our results for the relationship of working capital management and shareholder value indicate that a shorter CCC increases shareholder value, with longer payment terms having the highest and most significant effect.

The positive relationships of payables management in our regression analysis provide new evidence, as most previous studies found a negative relationship between payables management and profitability, which contradicts theory.

Considering the currently deteriorating trend in working capital management, the results highlight the necessity that managers should give greater priority to working capital optimization. Otherwise, they miss the opportunity that a shorter cash conversion, achieved through a combination of inventory, receivables and payables management, rises both profitability and shareholder value. For increased profitability, managers should focus on receivables and inventory management, which can be addressed with tighter credit policies or tools of lean manufacturing. In contrast, for the creation of shareholder value, extending payments periods to suppliers is crucial.

Our results correspond with previous literature, except that the effect of extending accounts payables is positive. This positive relationship is in line with theory and can be attributed to the value orientation of both dependent variables. We conclude that extending payment terms is particularly important in the long-term creation of shareholder value, whereas prompt payments increase profits in the short-run.

This study is one of the few to analyse the relationship of working capital management and shareholder value and advances the research topic on the impact of working capital management in the German market.sm

\section{References}

Bratianu, C. (2018). Intellectual capital research and practice: 7 myths and one golden rule. Management \& Marketing - Challenges for the Knowledge Society, 13(2), 859-879. https://doi.org/10.2478/mmcks-2018-0010

Brotherson, W.T., Eades, K.M., Harris, R. S., \& Higgins, R.C. (2014). Company Valuation in Mergers and Acquisitions: How is discounted Cash flow Applied by Leading Practitioners? Journal of Applied Finance, 2, 43-51.

Charifzadeh, M. \& Taschner, A. (2017). Management accounting and control: Tools and concepts in a European context, Wiley-Vch.

Deloitte (2017). Working Capital: Flüssige Mittel und gebundenes Kapital [Working Capital: Cash and tied-up capital] Retrieved April 10, 2020 from https://www2.deloitte.com/de/de/pages/finance/articles/ working-capital.html

Deloof, M. (2003). Does Working Capital Management Affect Profitability of Belgian firms?, Journal of Business Finance \& Accounting, 30 (3-4), 573-588. https://doi.org/10.1111/1468-5957.00008

Deutsche Börse AG (2017). Leitfaden zu den Aktienindizes der Deutsche Börse AG [Guide to the stock indices of the German Stock Exchange] Retrieved April 10, 2020 from http://www.deutsche-boerse-cashmarket.com/blob/2940666/e0425be189d5f2952d874bd 9cdb8b775/data/Leitfaden-zu-den-Aktieninidzes.pdf

Eljelly, A. M. (2004). Liquidity - profitability trade off: An empirical investigation in an emerging market, International Journal of Commerce and Management, 14 (2), 48-61. https://doi.org/10.1108/10569210480000179

Enqvist, J., Graham, M. \& Nikkinen, J. (2014). The impact of working capital management on firm profitability in different business cycles: Evidence from Finland, Research in International Business and Finance, 32, 36-49.

https://doi.org/10.1016/j.ribaf.2014.03.005 
Faulkender, M. \& Wang, R. (2006). Corporate Financial Policy and the Value of Cash, The Journal of Finance, 61 (4), 1957-1990 https://doi.org/10.1111/j.1540-6261.2006.00894.x

García-Teruel, P. J. \& Martínez-Solano, P. (2007). ‘Effects of working capital management on SME profitability', 3 (2), 164-177. https://doi.org/10.1108/17439130710738718

Gitman, L. J. \& Zutter, C. J. (2015). Principles of Managerial Finance, Boston: Pearson.

Gleich, R., Horváth, P. \& Michel, U., eds. (2011). FinanzControlling: Strategische und operative Steuerung der Liquidität [Financial Controlling: Strategic and operational management of liquidity], München, HaufeLexware GmbH \& Co. KG.

Greene, W. H. (2003). Econometric analysis, 5th edn, Upper Saddle River, NJ, Prentice-Hall. https://doi.org/10.4236/gep.2015.310006

Hausman, J. A. (1978). Specification Tests in Econometrics, Econometrica, 46, (6), 1251-1272. https://doi.org/10.12691/jfe-2-5-6

Hoke, M. (2002). Unternehmensbewertung auf Basis EVA: Erfahrungen bei der Implementierung eines EVAbasierten Bewertungsmodells [Company evaluation based on EVA: experience in implementing an EVAbased valuation model], Der Schweizer Treuhänder, 76 (9), 765-770. Retrieved April 10, 2020 from http://www.bwlonline.ch/500KapitelOrdner/510KapitelOrdner/515Kapit elOrdner/Unternehmensbewertung\%20auf\%20Basis\%2 OEVA.pdf

Holler, A. (2009). New Metrics for Value-Based Management: Enhancement of Performance Measurement and Empirical Evidence on ValueRelevance, Wiesbaden: Gabler.

Isaic, R., Smirna, T., \& Paun, C. (2019). A critical view on the mainstream theory of economic cycles. Management \& Marketing - Challenges for the Knowledge Society, 14(1), 48-58. https://doi.org/10.2478/mmcks-2019-0004

Jose, M. L., Lancaster, C. \& Stevens, J. L. (1996). Corporate returns and cash conversion cycles, Journal of Economics and Finance, 20 (1), 33-46. https://doi.org/10.1007/BF02920497

Kieschnick, R., Laplante, M. \& Moussawi, R. (2013). Working Capital Management and Shareholders' Wealth, Review of Finance, 17, (5), 1827-1852. https://doi.org/10.1093/rof/rfs043

Knauer, T. \& Wöhrmann, A. (2013). Working capital management and firm profitability, 24 (1), 77-87. https://doi.org/10.1007/s00187-013-0173-3

Koller, T., Goedhart, M. \& Wessels, D. (2015). Valuation: Measuring and Managing the Value of Companies, University Edition, 6th edn, New York, NY, John Wiley \& Sons. Retrieved April 10, 2020 from http://elibrary.bsu.az/books 200/N 1.pdf

Lazaridis, I. \& Tryfonidis, D. (2006). The relationship between Working Capital Management and Profitability of Listed Companies in the Athens Stock Exchange, Journal of Financial Management and Analysis, 19 (1), 26-35. Retrieved April 10, 2020 from https://papers.ssrn.com/sol3/papers.cfm?abstract id=9 $\underline{31591}$
Lind, L., Pirttilä, M., Viskari, S., Schupp, F. \& Kärri, T. (2012). Working capital management in the automotive industry: financial value chain analysis, Journal of Purchasing and Supply Management, 18 (2), 92-100. https://doi.org/10.1016/j.pursup.2012.04.003

Lyngstadaas, H. \& Berg, T. (2016). Working capital management: evidence from Norway, International Journal of Managerial Finance, 12 (3), 295-313. https://doi.org/10.24052/JBRMR/V12IS01/TQRBWCMA FPEFTNE

Meyer, S. \& Lüdtke, J.-P. (2006). Der Einfluss von Working Capital auf die Profitabilität und Kreditwürdigkeit von Unternehmen [The impact of working capital on the profitability and creditworthiness of companies], FinanzBetrieb, 10, 609-614. Retrieved April 10, 2020 from https://www.econbiz.de/Record/der-einfluss-vonworking-capital-auf-die-profitabilit\%C3\%A4t-undkreditw\%C3\%BCrdigkeit-von-unternehmen-meyersteffen/10003375399

Moodley, T., Ward, M. \& Muller, C. (2016). The relationship between the management of payables and the return to investors, South African Journal of Accounting Research, 31 (1), 35-43. https://doi.org/10.1080/10291954.2015.1105555

Mooi, E., \& Sarstedt, M. (2011). A Concise Guide to Market Research. Springer Berlin Heidelberg. https://doi.org/10.1007/978-3-642-12541-6

Newey, W. K., \& West, K. D. (1987). A Simple, Positive Semi-Definite, Heteroskedasticity and Autocorrelation Consistent Covariance Matrix. Econometrica, 55(3), 703. https://doi.org/10.2307/1913610

Padachi, K. (2006). Trends in Working Capital Management and its Impact on Firm's Performance: An Analysis of Mauritian Small Manufacturing Firms, 2 (2), 45-58. Retrieved April 10, 2020, from http://citeseerx.ist.psu.edu/viewdoc/download?doi=10.1. 1.475.2653\&rep=rep1\&type=pdf

Pais, M. A. \& Gama, P. M. (2015). Working capital management and SMEs profitability: Portuguese evidence, International Journal of Managerial Finance, 11 (3), 341-358. https://doi.org/10.1108/lJMF-11-2014-0170

Pauna, C. (2019). Low risk trading algorithm based on the price cyclicality function for capital markets. Management \& Marketing - Challenges for the Knowledge Society, 14(1), 80-89. https://doi.org/10.2478/mmcks-2019-0006

Popescu, G. H. (2018). Participation in the sharing economy: Labor, exchange, and consumption. An empirical analysis. Journal of Self-Governance and Management Economics, 6(1), 122-127. https://doi.org/10.22381/JSME6120185

PricewaterhouseCoopers (2018). Working Capital Report 2018/19: Navigating uncertainty: PwC's annual global Working Capital Study. Retrieved April 10, 2020 from https://www.pwc.com/gx/en/working-capitalmanagement-services/assets/working-capitalopportunity-2017-2018.pdf

PricewaterhouseCoopers (2017). Working-Capital Management: Und wie steht es um Ihre Liquidität? [Working Capital Management: And what about your liquidity?] Retrieved April 10, 2020 from https://www.pwc.de/de/deals/working-capitalmanagement-studie-2017.pdf 
Raheman, A. \& Nasr, M. (2007). Working Capital Management And Profitability - Case of Pakistani Firms, 3 (1), 278-300. Retrieved April 10, 2020 from http://www.bizresearchpapers.com/Paper\%2019.pdf

Rappaport, A. (1986). Creating Shareholder Value: The New Standard for Business Performance, New York: Free Press.

Rappaport, A. (1998). Creating shareholder value: A guide for managers and investors, New York: Free Press.

Rappaport, A. (1999). Shareholder value: Ein Handbuch für Manager und Investoren [Shareholder value: A guide for managers and investors], Stuttgart: SchäfferPoeschel Verlag.

REL Consultancy (2017). Europe Working Capital Survey. Retrieved April 10, 2020 from http://www.relconsultancy.com/research/2017/euworking-capital-survey-1708/

Schall, L. D. \& Haley, C. W. (1986). Introduction to Financial Management, 4th edn, New York: McGraw-Hill.

Sharma, A. K. \& Kumar, S. (2011). Effect of Working Capital Management on Firm Profitability, Global Business Review, 12 (1), 159-173. https://doi.org/10.1177/097215091001200110

Shin, H.-H. \& Soenen, L. (1998). 'Efficiency of Working Capital Management and Corporate Profitability', Financial Practice \& Education, 8, 37-45. Retrieved April 10, 2020 from http://www.redibw.de/db/ebsco.php/search.ebscohost.com/login.aspx \%3fdirect\%3dtrue \%26db\%3dbth\%26AN\%3d1712459\% 26site\%3dehost-live

Simons, R. (2000). Performance measurement \& control systems for implementing strategy: Text \& cases, Upper Saddle River, N.J., Prentice-Hall. ISBN-13: 9780132340069

Singh, H. P. \& Kumar, S. (2014). Working capital management: a literature review and research agenda, 6 (2), 173-197. Retrieved April 10, 2020 from https://econpapers.repec.org/article/emeqrfmpp/v 3a6 3ay 3a2014 3ai 3a2 3ap 3a173-197.htm

Singh, H. P., Kumar, S. \& Colombage, S. (2017). Working capital management and firm profitability: a metaanalysis, 9 (1), 34-47. https://doi.org/10.1108/QRFM-06-2016-0018

Singhania, M. \& Mehta, P. (2017). Working capital management and firms' profitability: evidence from emerging Asian countries, South Asian Journal of Business Studies, 6 (1), 80-97. https://doi.org/10.1108/APJBA-06-2017-0057

Stern, J. M. \& Shiely, J. S. (2001). The EVA Challenge: Implementing Value-Added Change in an Organization, New York: John Wiley \& Sons.

\section{$\triangle$ Correspondence}

\section{Konstantin B. Kostin}

Saint-Petersburg State University of Economics

Sadovaya str. 21, office 2094 St. Petersburg 191023, Russia

E-mail: kost_kos@mail.ru
Subic, J., Vasiljevic, Z., \& Andrei, J. (2010). The impact of FDI on the European economic development in the context of diversification of capital flows. Proceedings of the 14th International Business Information Management Association, Business Transformation through Innovation and Knowledge Management: An Academic Perspective, Istanbul, Turkey, 23-24.

Taghizadeh, K.V., Ghanavati, E., Akbari, K.M. \& Ebrati, M. (2012). Working capital management and corporate performance: evidence from Iranian companies, Procedia - Social and Behavioral Sciences, 62, 13131318.

https://doi.org/10.1016/j.sbspro.2012.09.225

Van der Wielen, L., Van Alphen, W., Bergen, J. \& Lindow, P. (2006). International Cash Management: A Practical Guide to Managing Cash Flows, Liquidity, Working Capital and Short-term Financial Risks, Driebergen: Riskmatrix.

Valaskova, K., Kliestik, T., \& Kovacova, M. (2018). Management of financial risks in Slovak enterprises using regression analysis. Oeconomia Copernicana, 9(1), 105-121.

https://doi.org/10.24136/oc.2018.006

Wang, Y.-J. (2002). Liquidity management, operating performance, and corporate value: evidence from Japan and Taiwan, Journal of Multinational Financial Management, 12 (2), 159-169. https://doi.org/10.1016/S1042-444X(01)00047-0

Westbrook, L., Pera, A., Neguriță, O., Grecu, I., \& Grecu, G. (2019). Real-time Data-driven technologies: Transparency and fairness of automated decisionmaking process governed by intricate algorithms. Contemporary Readings in Law and Social Justice, 11(1), 45-50. https://doi.org/10.22381/CRLSJ11120197

Whiting, E. (1986). A Guide to Business Performance Measurements, Palgrave Macmillan UK. https://doi.org/10.1007/978-1-349-07472-3 3

Wöhrmann, A., Knauer, T. \& Gefken, J. (2012). Kostenmanagement in Krisenzeiten: Rentabilitätssteigerung durch Working Capital Management? [Cost management in times of crisis: Profitability increase through Working Capital Management?], Controlling \& Management Review, 3, 83-88. https://doi.org/10.1365/s12176-012-0649-2

Wooldridge, J. M. (2016). Introductory econometrics: A modern approach, Boston, MA: Cengage Learning.

Young, S. D. \& O'Byrne, S. F. (2001). EVA® and valuebased management: A practical guide to implementation, New York NY: McGraw-Hill. 